\title{
Sequential Detection of Lipids, Metabolites and Proteins in One Tissue for Improved Cancer Differentiation Accuracy
}

\author{
Haiyan $\mathrm{Lu}^{1}$, Hua Zhang ${ }^{1}$, Konstantin Chingin ${ }^{2}$, Yiping $\mathrm{Wei}^{3}$, Jiaquan $\mathrm{Xu}^{2}$, Mufang $\mathrm{Ke}^{1}$, Keke Huang ${ }^{1}$, \\ Shouhua Feng ${ }^{1 *}$, Huanwen Chen ${ }^{2 *}$
}

${ }^{1}$ State Key Laboratory of Inorganic Synthesis and Preparative Chemistry, College of Chemistry, Jilin University, Changchun 130012, P. R. China

${ }^{2}$ Jiangxi Key Laboratory for Mass Spectrometry and Instrumentation, East China University of Technology, Nanchang 330013, P. R. China

${ }^{3}$ Second Affiliated Hospital of Nanchang University, Nanchang 330006, P. R. China

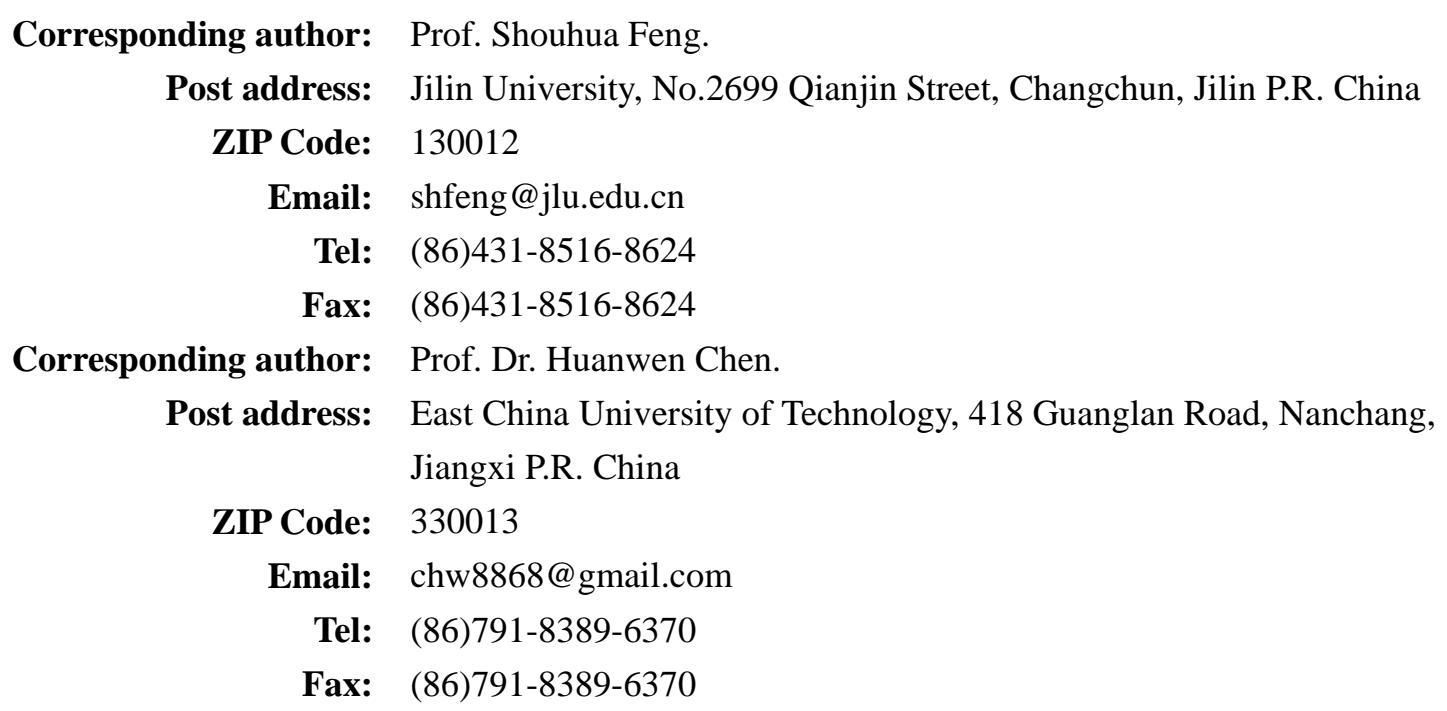

Additional information as follows: iEESI-MS Experiment and Working Conditions; Optimization of Experimental Conditions (including Experimental Parameters and Extraction Solutions); The Reproducibility Test of iEESI-MS and ESI-MS Experiments. 
iEESI-MS Experiment and Working Conditions. The whole tissue sample was allowed to equilibrate to room temperature before iEESI-MS analysis. The small pieces of tissue samples of triangle shape (ca. $2.0 \mathrm{~mm}^{3}$ ) were cut from different locations with the same morphology for each measurement. The fused silica capillary was inserted into the bulk tissue sample (ca. $2.0 \mathrm{~mm}^{3}$ ). The distance between the fused silica capillary and the apex of tissue sample was $1.0 \mathrm{~mm}$. The distance between the tissue sample and the inlet of mass spectrometer was $6.0 \mathrm{~mm}$. The extraction solution biased with a high voltage $(+4.5 \mathrm{kV})$ was infused at $1.0 \mu \mathrm{L} / \mathrm{min}$ into the tissue sample by a syringe pump ( $250 \mu \mathrm{L}$, Harvard, MA, USA).

Full scan was collected at mass range of $\mathrm{m} / \mathrm{z}$ 50-2000 under positive ion detection mode. The MS instrumental conditions were as follows: the capillary temp of $200{ }^{\circ} \mathrm{C}$, the tube lens voltage of $100 \mathrm{~V}$, and the capillary voltage of $10 \mathrm{~V}$. Chemical assignments were based on high-resolution mass measurement, comparisons with literatures, NIST/EPI/NIH Mass Spectral Library, and collision-induced dissociation (CID) experiments. In CID experiments, precursor ions were isolated with window width of $1.5 \mathrm{Da}$, and normalized collision energy was $10-30 \%$. The spray voltage and capillary temperature were optimized (Figure S1). Other parameters were set as default values of the instrument.

\section{Optimization of Experimental Conditions}

Experimental Parameters. The experimental parameters including spray voltage and capillary temperature were optimized by evaluating the signal intensity of selected small metabolites (including $m / z, 132,147,156,164,170$, and 180), lipids (including $\mathrm{m} / \mathrm{z} 757$, 
773, 783, 799, 809, and 825), and protein ions (including $m / z, 886,941,1004,1075,1158$ and 1254). Figure S1A, S1C, and S1E in left column show the change of signal intensity of selected small metabolites, lipids and protein ions with spray voltage, respectively. It can be seen that the signal intensity of small metabolites (Figure S1A) decreased with the spray voltage within 4.0-4.5 kV, while consistently increased within 4.5-7.0 kV. The signal intensities of lipids (Figure S1C) increased with the spray voltage within 4.0-4.5 kV and maximized at $4.5 \mathrm{kV}$, while decreased within 4.5-7.0 kV. For protein ions (Figure S1E), their signal intensities decreased with the spray voltage within $4.0-7.0 \mathrm{kV}$.

Similarly, Figure S1B, S1D and S1F in right column show the change of signal intensity of above-mentioned small metabolites, lipids and protein ions with capillary temperature, respectively. It could be seen that the signal intensity of small metabolites (Figure S1B) decreased with the capillary temperature within $50-400{ }^{\circ} \mathrm{C}$, whereas the signal intensity of evaluated lipids (Figure S1D) and protein ions (Figure S1F) reached their maximal level at $200{ }^{\circ} \mathrm{C}$. Despite the signal intensity of all evaluated ions showed different change trends with spray voltage and capillary temperature, their signal intensity kept at the same order of magnitude under each condition. Taking the signal intensity of all evaluated ions into considerations, the spray voltage at $4.5 \mathrm{kV}$ and capillary temperature at $200{ }^{\circ} \mathrm{C}$ were selected. Illustrate that optimization experiments of spray voltage and capillary temperature were performed by using $\mathrm{CH}_{3} \mathrm{OH} / \mathrm{H}_{2} \mathrm{O} / \mathrm{CH}_{3} \mathrm{COOH}(\mathrm{v} / \mathrm{v} / \mathrm{v}, 35 / 65 / 2.5)$ as extractive solvent, because earlier experiments revealed that small metabolites, lipids and proteins could be simultaneously detected under this extractive solvent (Figure S2F). 
Extraction Solutions. In iEESI-MS, due to unique extraction/ionization process occurring inside the inner part of a bulk sample, the ideal mass spectral signals were highly correlated with solvents used for internal extraction of a bulk sample with multiple components. To screen suitable solvents for favorable extraction/ionization of small metabolites, lipids and proteins originating from single pieces of human lung tissue sample, porcine lung tissue samples, which are readily available as a xenogeneic alternative to human lung for research purposes, were chosen for parameter optimization. To explore solvents favorable for the extraction of small metabolites, a series of experiments were conducted using each newly loaded individual porcine lung tissues with different solvents including $\mathrm{H}_{2} \mathrm{O}$ (Figure S2A), $\mathrm{CH}_{3} \mathrm{OH}$ (Figure S2B), $\mathrm{CH}_{3} \mathrm{CH}_{2} \mathrm{OH}$ (Figure S2C), $\mathrm{CH}_{3} \mathrm{COOH}$ (Figure S2D), and $\mathrm{CH}_{3} \mathrm{COCH}_{3}$ (Figure S2E), etc. However, the mass spectra obtained with all solvents showed that only lipids in the mass range of $\mathrm{m} / \mathrm{z}$ 700-900 and no small metabolites were acquired. To be more precisely, 21 solvents composed with $\mathrm{CH}_{3} \mathrm{OH}$ and $\mathrm{H}_{2} \mathrm{O}$ at different ratio $(0-100 \%)$ were also tested to achieve the best composition for extraction/ionization of lipids. As the result, the solvent of $\mathrm{CH}_{3} \mathrm{OH} / \mathrm{H}_{2} \mathrm{O}(\mathrm{v} / \mathrm{v}, 35 / 65)$ was chosen for iEESI-MS to profile lipids in the lung tissue, because the highest abundance and density of lipids were observed in the mass spectra. Excitedly, the chemical profiling of small metabolites was also obtained using the solvent of $\mathrm{CH}_{3} \mathrm{OH} / \mathrm{H}_{2} \mathrm{O}(\mathrm{v} / \mathrm{v}, 35 / 65)$ after continuous extraction for ca. 50-80 min. Note that specific time depends on how much tissue material was loaded for the iEESI process. Then, a series of acetone (including $0.1 \%, 0.5 \%, 1.0 \%, 5.0 \%, 10.0 \%$, $15.0 \%, 20.0 \%, 25.0 \%, 30.0 \%, 35.0 \%, 40.0 \%, 45.0 \%, 50.0 \%, 55.0 \%$ and $60.0 \%)$ and acetic acid (including $0.1 \%, 0.5 \%, 1.0 \%, 1.5 \%, 2.0 \%, 2.5 \%, 3.0 \%, 3.5 \%, 4.0 \%, 4.5 \%, 5.0 \%$, 
$10.0 \%, 15.0 \%, 20.0 \%, 25.0 \%, 30.0 \%, 35.0 \%$ and $40.0 \%)$ were added into the solution of $\mathrm{CH}_{3} \mathrm{OH} / \mathrm{H}_{2} \mathrm{O}(\mathrm{v} / \mathrm{v}, 35 / 65)$ to prepare the working solution for proteins analysis, respectively. The results showed that the signal levels of proteins were optimal using acetic acid at 10.0\%. As shown in Figure S3, the protein ions corresponding to $\alpha$ and $\beta$ subunits of hemoglobin with wide charge state distributions (CSDs) in a relatively high mass range (m/z 600-1900) were detected. Consequently, the extraction solution $\mathrm{CH}_{3} \mathrm{OH} / \mathrm{H}_{2} \mathrm{O}(\mathrm{v} / \mathrm{v}$, 35/65) and $\mathrm{CH}_{3} \mathrm{OH} / \mathrm{H}_{2} \mathrm{O} / \mathrm{CH}_{3} \mathrm{COOH}(\mathrm{v} / \mathrm{v} / \mathrm{v}, 35 / 65 / 10)$ were selected for sequential detection of lipids, small metabolites, and proteins in a single tissue sample.

Besides, earlier experiments showed that lipids, small metabolites and proteins from a single tissue sample could be simultaneously detected using $\mathrm{CH}_{3} \mathrm{OH} / \mathrm{H}_{2} \mathrm{O} / \mathrm{CH}_{3} \mathrm{COOH}(\mathrm{v} / \mathrm{v} / \mathrm{v}$, 35/65/2.5) (Figure S2F). Full scan MS data was collected using a homemade iEESI ion source coupled with linear trap quadruple (LTQ) mass spectrometer controlled by XCalibur 2.0 software (Thermo Scientific, San Jose, CA). The MS instrumental conditions were as follows: the spray voltage of $5.5 \mathrm{kV}$, the capillary temperature of $150{ }^{\circ} \mathrm{C}$, the tube lens voltage of $100 \mathrm{~V}$, and the capillary voltage of $10 \mathrm{~V}$. The flow rate of extraction solution was $1.0 \mathrm{uL} / \mathrm{min}$. All spectra acquisition was at mass range of $\mathrm{m} / \mathrm{z} 50-2000$ in positive ion detection mode.

\section{The Reproducibility Test of iEESI-MS.}

The reproducibility of iEESI-MS method has been characterized in our recent study using pork tissue samples. ${ }^{1}$ To further validate the reproducibility, we carried out the reproducibility test on iEESI-MS by analysis of lipids and proteins in pork lung tissue 
samples using the extraction solution of $\mathrm{CH}_{3} \mathrm{OH} / \mathrm{H}_{2} \mathrm{O}$ (v/v, 35/65) and $\mathrm{CH}_{3} \mathrm{OH} / \mathrm{H}_{2} \mathrm{O} / \mathrm{CH}_{3} \mathrm{COOH}(\mathrm{v} / \mathrm{v} / \mathrm{v}, 35 / 65 / 10)$, respectively. The iEESI-MS mass spectra of seven replicates were shown in Figure S4, it was evident that the mass spectral profiles of each measurement have good consistency. The ions of lipids (including $m / z 757,773$ and 799) and proteins (including $\mathrm{m} / \mathrm{z}, 886,941$ and 1075) were used for evaluation of reproducibility of each measurement. The Table $\mathrm{S} 1$ indicates that the relative standard deviation (RSD) of each measurement was 5.9-8.4\%. These results indicated the good reproducibility of iEESI-MS for tissue analysis.

\section{ESI-MS Experiments.}

For reference, the off-line extraction solution of a single porcine lung tissue sample was analyzed by direct infusion ESI-MS experiments. The workflow of extraction solution preparation of a single tissue sample was shown in Figure S5. First, the extraction solution of $\mathrm{CH}_{3} \mathrm{OH} / \mathrm{H}_{2} \mathrm{O}(\mathrm{v} / \mathrm{v}, 35 / 65)$ and $\mathrm{CH}_{3} \mathrm{OH} / \mathrm{H}_{2} \mathrm{O} / \mathrm{CH}_{3} \mathrm{COOH}(\mathrm{v} / \mathrm{v} / \mathrm{v}, 35 / 65 / 10)$ were added into centrifuge tubes (from A to $F$ ) and $G$ centrifuge tube, respectively. The extraction solution in each centrifuge tube was $50 \mu \mathrm{L}$. Second, ca. $2.0 \mathrm{mg}$ porcine lung tissue sample was placed into the A centrifuge tube for $1 \mathrm{~min}$, and then it was sequentially transferred into B, C, D, E, F, and G centrifuge tube after $1 \mathrm{~min}, 10 \mathrm{~min}, 20 \mathrm{~min}, 30 \mathrm{~min}, 40 \mathrm{~min}$, and 50 min, respectively. The tissue sample was taken out after $1 \mathrm{~min}$ in $\mathrm{G}$ centrifuge tube. Third, the extraction solution was pumped through a syringe pump at the flow rate of $3.0 \mu \mathrm{L} / \mathrm{min}$ for ESI-MS analysis. In ESI-MS, the spray voltage of $3.0 \mathrm{kV}$, the capillary temperature of $200{ }^{\circ} \mathrm{C}$, the tube lens voltage of $100 \mathrm{~V}$, and the capillary voltage of $10 \mathrm{~V}$, and $\mathrm{N}_{2}$ (Jiangxi Guoteng Gas Co., Ltd., China) pressure was 1.0 MPa. 
A
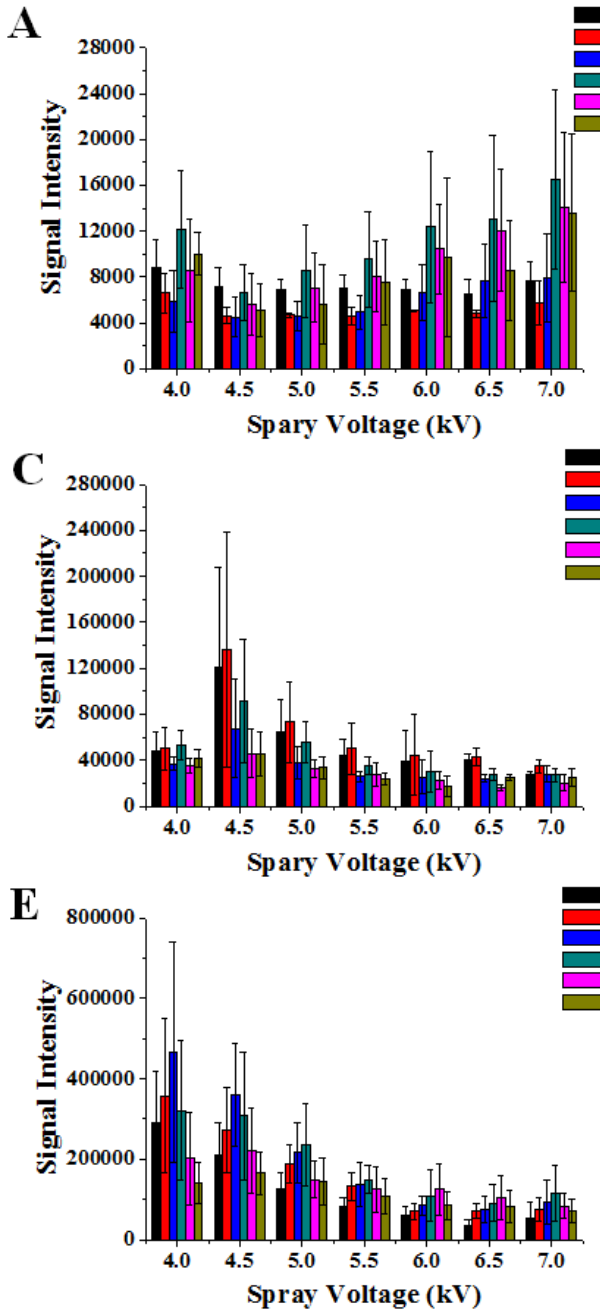

B
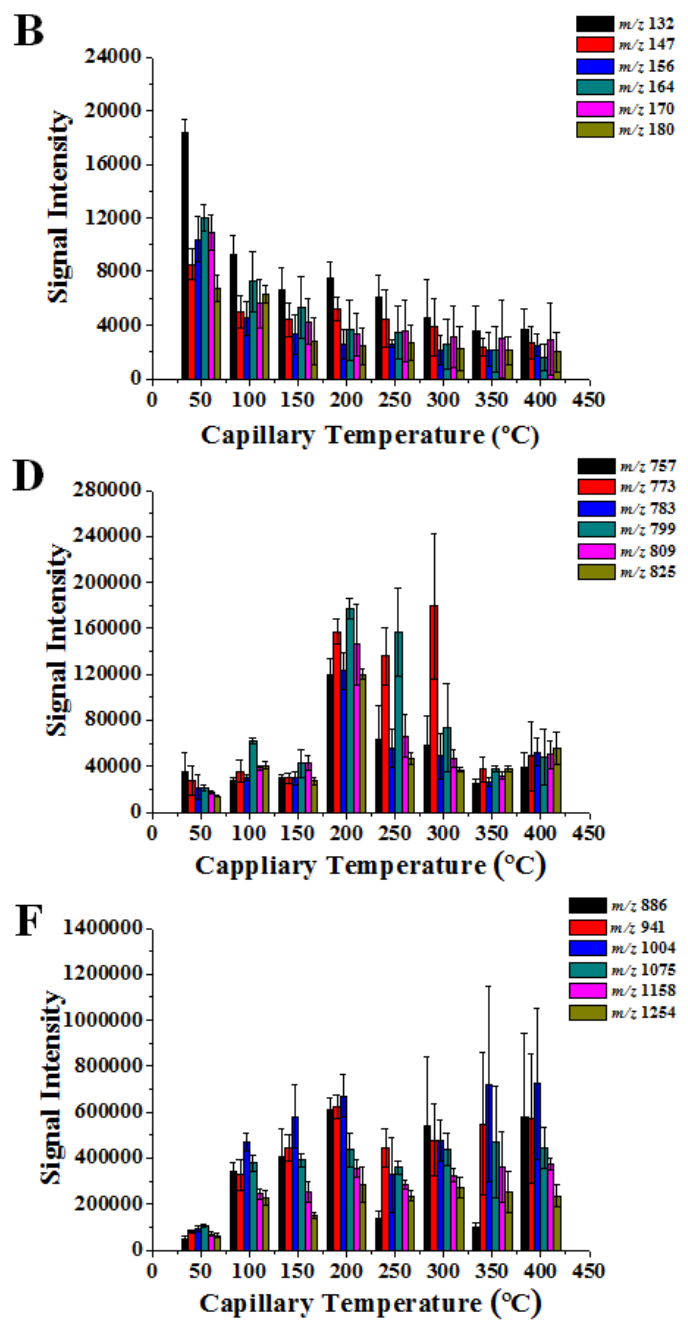

Figure S1. Optimization of experimental parameters. Signal intensities of small metabolites, lipids and protein ions at different spray voltages ((A), (C) and (E) in left column) and capillary temperature ((B), (D) and (F) in right column). 

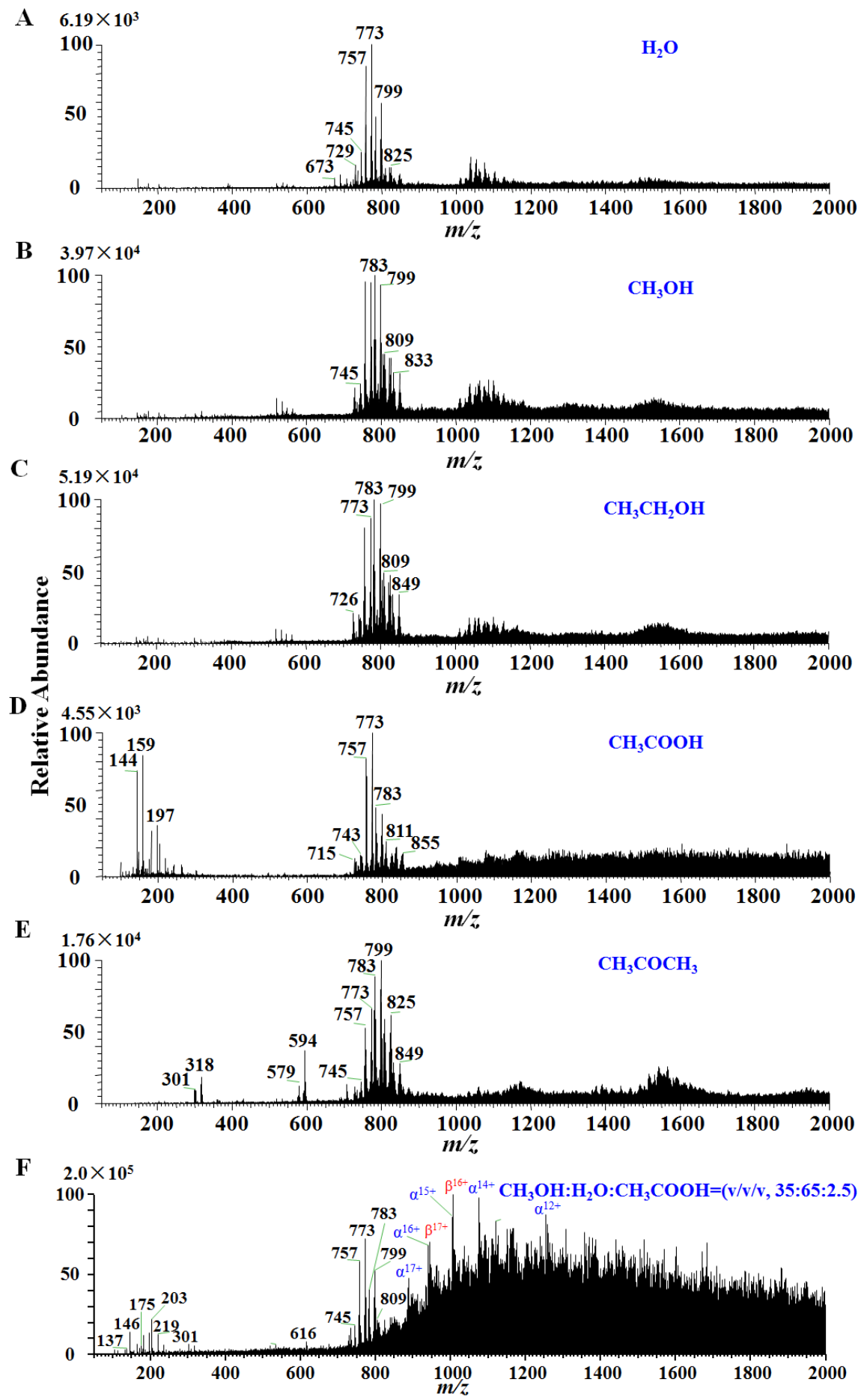

Figure S2. iEESI-MS of porcine lung tissue obtained with different extraction solutions. (A) $\mathrm{H}_{2} \mathrm{O}$, (B) $\mathrm{CH}_{3} \mathrm{OH}$, (C) $\mathrm{CH}_{3} \mathrm{CH}_{2} \mathrm{OH}$, (D) $\mathrm{CH}_{3} \mathrm{COOH}$, (E) $\mathrm{CH}_{3} \mathrm{COCH}_{3}$ and (F) $\mathrm{CH}_{3} \mathrm{OH} / \mathrm{H}_{2} \mathrm{O} / \mathrm{CH}_{3} \mathrm{COOH}$ (v/v/v, $35 / 65 / 2.5)$. 


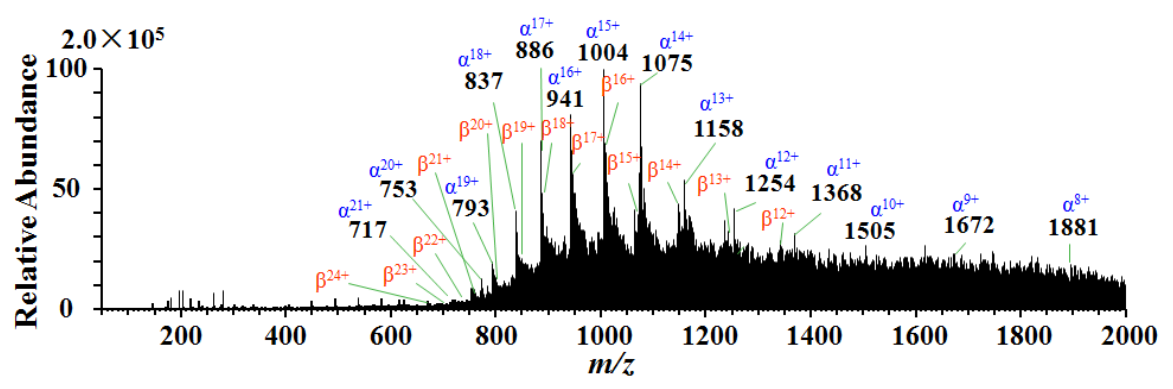

Figure S3. iEESI-MS of porcine lung tissue obtained using $\mathrm{CH}_{3} \mathrm{OH} / \mathrm{H}_{2} \mathrm{O} / \mathrm{CH}_{3} \mathrm{COOH}(\mathrm{v} / \mathrm{v} / \mathrm{v}$, $35 / 65 / 10$ ) as extraction solution. 

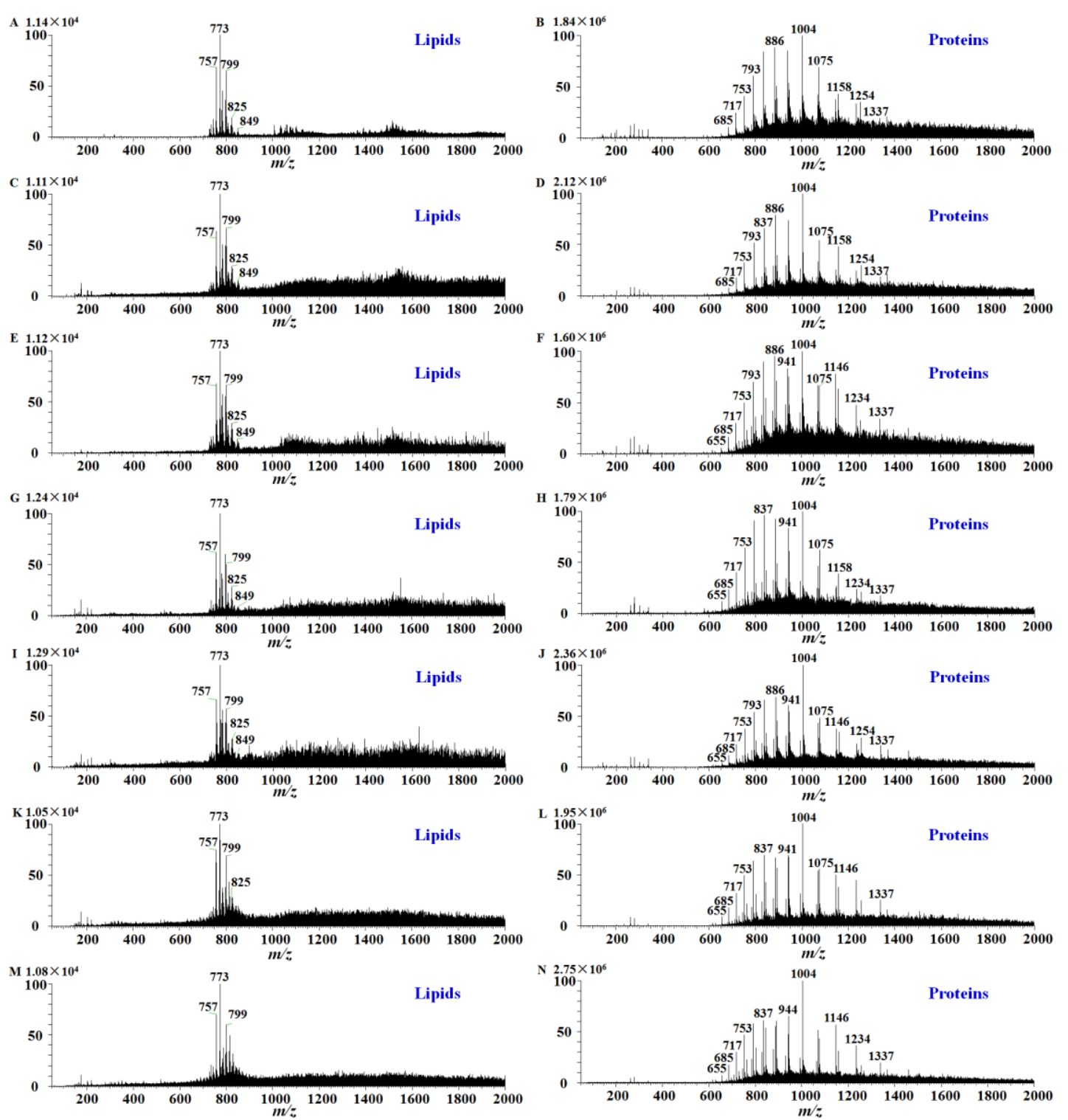

Figure S4. The reproducibility test of iEESI-MS by analysis of pork lung tissue sample in seven replicates. (A), (C), (E), (G), (I), (K) and (M) in left column correspond to the MS profiles of lipids obtained using the extraction solution of $\mathrm{CH}_{3} \mathrm{OH} / \mathrm{H}_{2} \mathrm{O}$ (v/v, 35/65) by iEESI-MS, (B), (D), (F), (H), (J), $(\mathrm{L})$ and $(\mathrm{N})$ in right column correspond to the MS profiles of proteins obtained using the extraction solution of $\mathrm{CH}_{3} \mathrm{OH} / \mathrm{H}_{2} \mathrm{O} / \mathrm{CH}_{3} \mathrm{COOH}(\mathrm{v} / \mathrm{v} / \mathrm{v}, 35 / 65 / 10)$ by iEESI-MS. 


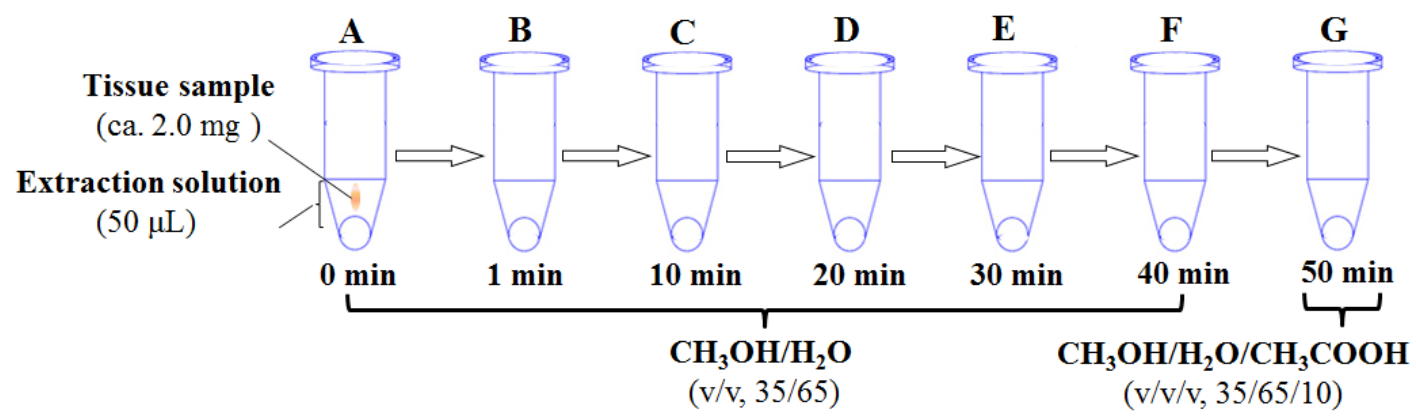

Figure S5. Schematic illustration of the extraction solution preparation for a single tissue sample analysis by ESI-MS. Centrifuge tubes from $\mathrm{A}$ to $\mathrm{F}$ were filled with the extraction solution of $\mathrm{CH}_{3} \mathrm{OH} / \mathrm{H}_{2} \mathrm{O}$ (v/v, 35/65). The centrifuge tube $\mathrm{G}$ was filled with $\mathrm{CH}_{3} \mathrm{OH} / \mathrm{H}_{2} \mathrm{O} / \mathrm{CH}_{3} \mathrm{COOH}(\mathrm{v} / \mathrm{v} / \mathrm{v}$, $35 / 65 / 10$ ) extraction solution. The extraction solution in each centrifuge tube was $50 \mu \mathrm{L}$. (Note: ca. 2.0 $\mathrm{mg}$ porcine lung tissue sample was placed into the A centrifuge tube for $1 \mathrm{~min}$, and then it was sequentially transferred into B, C, D, E, F, and G centrifuge tube after $1 \mathrm{~min}, 10 \mathrm{~min}, 20 \mathrm{~min}, 30 \mathrm{~min}, 40$ min, and $50 \mathrm{~min}$, respectively.) 

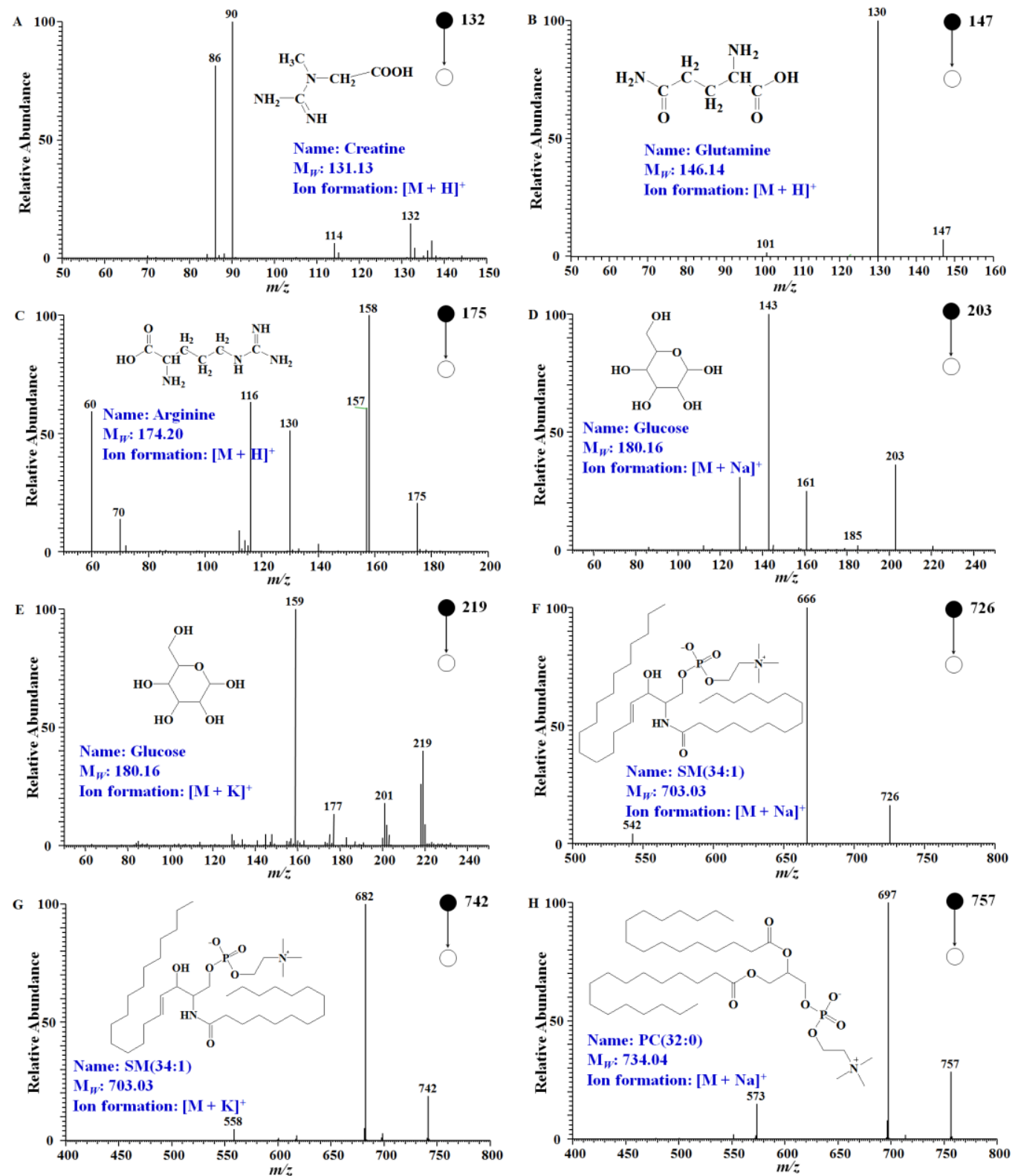

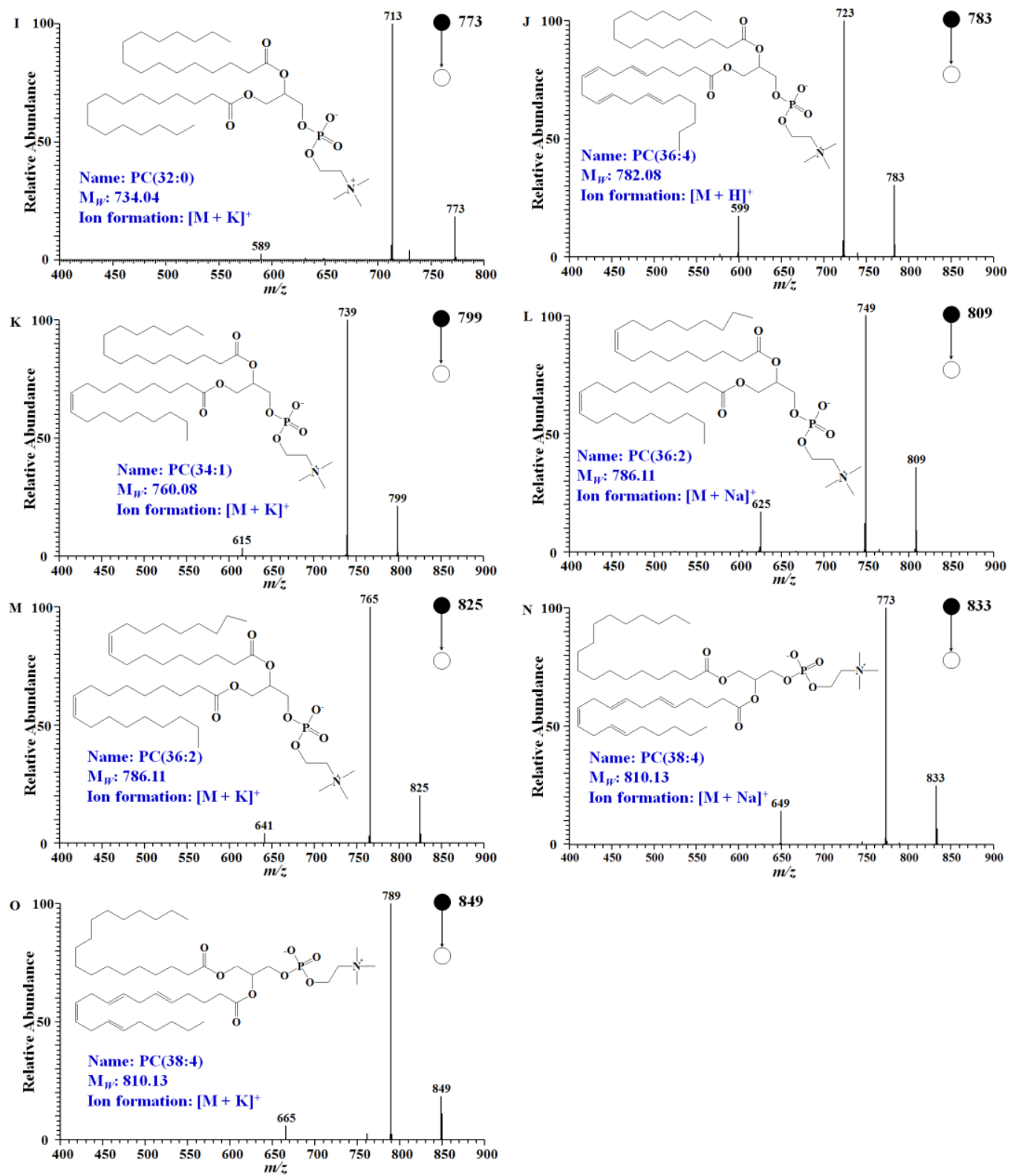

Figure S6. iEESI-MS/MS analysis of characteristic compounds in tissue samples. (A) $\mathrm{m} / \mathrm{z} 132$ $[\text { Creatine }+\mathrm{H}]^{+}$, (B) $m / z 147$ [Glutamine $\left.+\mathrm{H}\right]^{+}$, (C) $m / z 175$ [Arginine $\left.+\mathrm{H}\right]^{+}$, (D) $m / z 203$ [Glucose + $\mathrm{Na}]^{+}$, (E) $m / z 219[\text { Glucose }+\mathrm{K}]^{+}$, (F) $m / z, 726[\mathrm{SM}(34: 1)+\mathrm{Na}]^{+}$, (G) $m / z, 742[\mathrm{SM}(34: 1)+\mathrm{K}]^{+}$, (H) $m / z$ $757[\mathrm{PC}(32: 0)+\mathrm{Na}]^{+}$, (I) $m / z 773[\mathrm{PC}(32: 0)+\mathrm{K}]^{+},(\mathrm{J}) \mathrm{m} / z 783[\mathrm{PC}(36: 4)+\mathrm{H}]^{+}$, (K) $m / z 799[\mathrm{PC}(34: 1)$ $+\mathrm{K}]^{+}$, (L) $m / z 809[\mathrm{PC}(36: 2)+\mathrm{Na}]^{+}$, (M) $m / z 825[\mathrm{PC}(36: 2)+\mathrm{K}]^{+}$, (N) $m / z 833[\mathrm{PC}(38: 4)+\mathrm{Na}]^{+}$, and (O) $m / z 849[\mathrm{PC}(38: 4)+\mathrm{K}]^{+}$. 

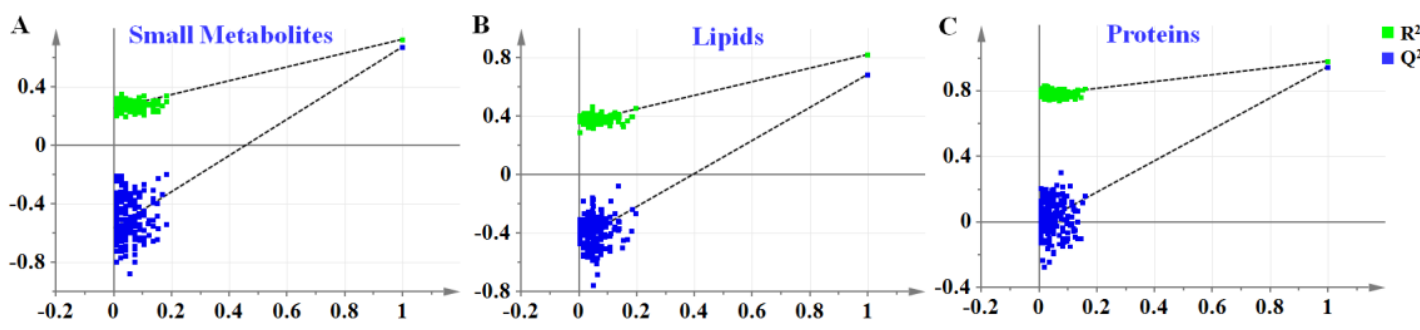

Figure S7. Validation of results with 200 permutation tests of PLS-DA models corresponding to OPLS-DA models, indicating that the model was not overfitted. (A) Small metabolites, (B) lipids, and $(\mathrm{C})$ proteins. 

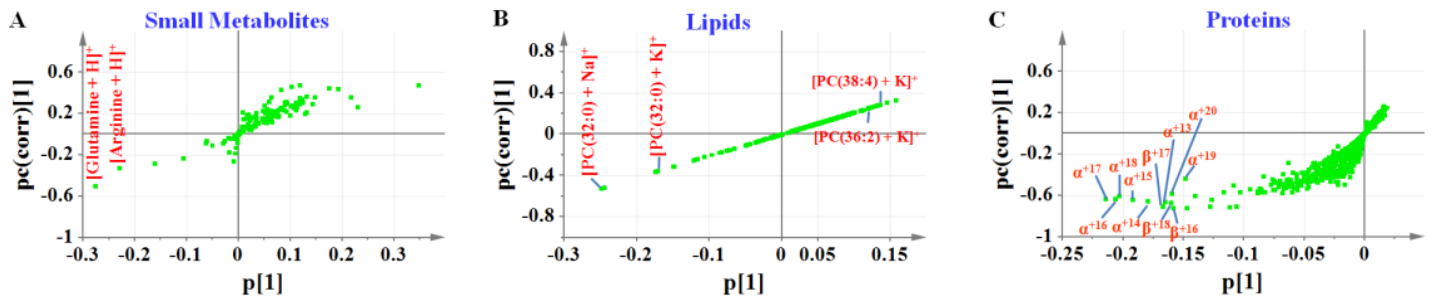

Figure S8. S-plots corresponding to the OPLS-DA models of cancerous and normal tissue samples. (A) Small metabolites, (B) lipids, and (C) proteins. 


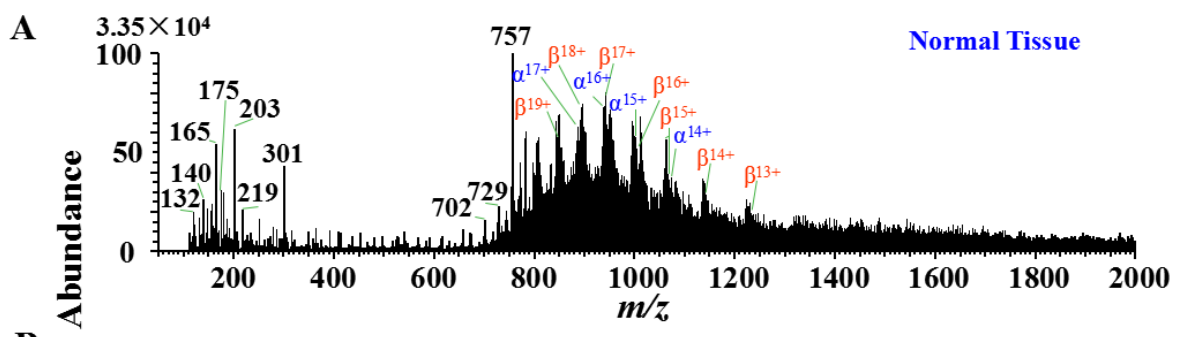

B $\odot 6.5 \times 10^{4}$

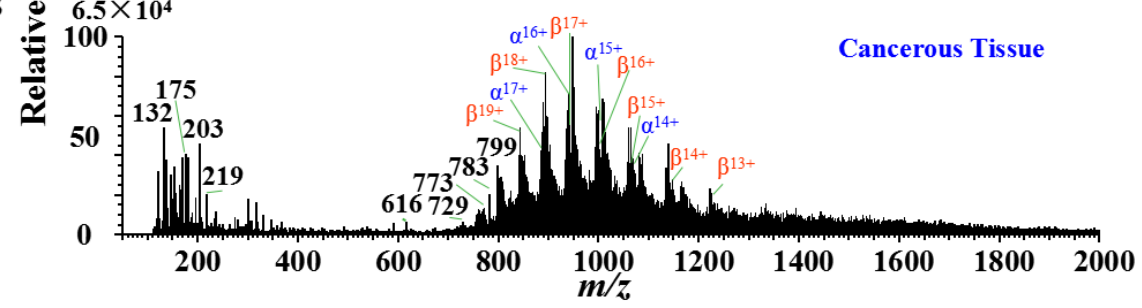

Figure S9. iEESI-MS of human lung tissue samples obtained using $\mathrm{CH}_{3} \mathrm{OH} / \mathrm{H}_{2} \mathrm{O} / \mathrm{CH}_{3} \mathrm{COOH}$ (v/v/v, 35/65/2.5) as extraction solution. (A) Normal tissue sample, (B) cancerous tissue sample. 
Table S1. The reproducibility test on iEESI-MS for pork lung tissue for seven replicates.

\begin{tabular}{|c|c|c|c|c|c|c|c|c|c|c|c|}
\hline \multirow[t]{2}{*}{ Compounds } & \multirow{2}{*}{$\begin{array}{c}\text { Observed } \\
\boldsymbol{m} / \mathbf{z} \\
886\end{array}$} & \multicolumn{7}{|c|}{ Signal intensity of observed $\mathrm{m} / \mathrm{z}$ of seven replicates } & \multirow{2}{*}{$\begin{array}{c}\begin{array}{c}\text { Average } \\
(\mathbf{n}=7)\end{array} \\
1560000.0\end{array}$} & \multirow{2}{*}{$\begin{array}{c}\text { SD } \\
130639.5\end{array}$} & \multirow{2}{*}{$\begin{array}{r}\text { RSD } \\
(\%) \\
8.4\end{array}$} \\
\hline & & 1620000.0 & 1680000.0 & 1520000.0 & 1660000.0 & 1620000.0 & 1300000.0 & 1520000.0 & & & \\
\hline \multirow{2}{*}{ Protein ions } & 1075 & 1270000.0 & 1150000.0 & 1060000.0 & 1110000.0 & 1140000.0 & 1080000.0 & 1190000.0 & 1142857.1 & 71113.6 & 6.2 \\
\hline & 757 & 7760.0 & 7060.0 & 7300.0 & 7700.0 & 8490.0 & 7900.0 & 7590.0 & 7685.7 & 456.1 & 5.9 \\
\hline \multirow[t]{2}{*}{ Lipids } & 773 & 11400.0 & 11100.0 & 11200.0 & 12400.0 & 12900.0 & 10500.0 & 10800.0 & 11471.4 & 867.4 & 7.6 \\
\hline & 799 & 7400.0 & 7360.0 & 7450.0 & 6220.0 & 7320.0 & 7250.0 & 6490.0 & 7070.0 & 498.5 & 7.1 \\
\hline
\end{tabular}


Table S2. Chemical assignment for the signals from tissue sample by iEESI-MS/MS.

\begin{tabular}{cccccc}
\hline No. & Compounds & Molecular formula & $m / z$ & Ion formation & MS/MS fragments \\
\hline 1 & Creatine & $\mathrm{C}_{4} \mathrm{H}_{9} \mathrm{~N}_{3} \mathrm{O}_{2}$ & 132 & {$[\mathrm{M}+\mathrm{H}]^{+}$} & $114 / 90 / 86$ \\
2 & Glutamine & $\mathrm{C}_{5} \mathrm{H}_{10} \mathrm{~N}_{2} \mathrm{O}_{3}$ & 147 & {$[\mathrm{M}+\mathrm{H}]^{+}$} & $130 / 101$ \\
3 & Arginine & $\mathrm{C}_{6} \mathrm{H}_{14} \mathrm{~N}_{4} \mathrm{O}_{2}$ & 175 & {$[\mathrm{M}+\mathrm{H}]^{+}$} & $158 / 157 / 130 / 116 / 70 / 60$ \\
4 & Glucose & $\mathrm{C}_{6} \mathrm{H}_{12} \mathrm{O}_{6}$ & 203 & {$[\mathrm{M}+\mathrm{Na}]^{+}$} & $185 / 161 / 143$ \\
5 & Glucose & $\mathrm{C}_{6} \mathrm{H}_{12} \mathrm{O}_{6}$ & 219 & {$[\mathrm{M}+\mathrm{K}]^{+}$} & $201 / 177 / 159$ \\
6 & $\mathrm{SM}(34: 1)$ & $\mathrm{C}_{39} \mathrm{H}_{79} \mathrm{~N}_{2} \mathrm{O}_{6} \mathrm{P}$ & 726 & {$[\mathrm{M}+\mathrm{Na}]^{+}$} & $666 / 542$ \\
7 & $\mathrm{SM}(34: 1)$ & $\mathrm{C}_{39} \mathrm{H}_{79} \mathrm{~N}_{2} \mathrm{O}_{6} \mathrm{P}$ & 742 & {$[\mathrm{M}+\mathrm{K}]^{+}$} & $683 / 559$ \\
8 & $\mathrm{PC}(32: 0)$ & $\mathrm{C}_{40} \mathrm{H}_{80} \mathrm{NO}_{8} \mathrm{P}$ & 757 & {$[\mathrm{M}+\mathrm{Na}]^{+}$} & $697 / 573$ \\
9 & $\mathrm{PC}(32: 0)$ & $\mathrm{C}_{40} \mathrm{H}_{80} \mathrm{NO}_{8} \mathrm{P}$ & 773 & {$[\mathrm{M}+\mathrm{K}]^{+}$} & $713 / 589$ \\
10 & $\mathrm{PC}(36: 4)$ & $\mathrm{C}_{42} \mathrm{H}_{81} \mathrm{NO}_{8} \mathrm{P}$ & 783 & {$[\mathrm{M}+\mathrm{H}]^{+}$} & $723 / 599$ \\
11 & $\mathrm{PC}(34: 1)$ & $\mathrm{C}_{42} \mathrm{H}_{82} \mathrm{NO}_{8} \mathrm{P}$ & 799 & {$[\mathrm{M}+\mathrm{K}]^{+}$} & $739 / 615$ \\
12 & $\mathrm{PC}(36: 2)$ & $\mathrm{C}_{44} \mathrm{H}_{84} \mathrm{NO}_{8} \mathrm{P}$ & 809 & {$[\mathrm{M}+\mathrm{Na}]^{+}$} & $749 / 625$ \\
13 & $\mathrm{PC}(36: 2)$ & $\mathrm{C}_{44} \mathrm{H}_{84} \mathrm{NO}_{8} \mathrm{P}$ & 825 & {$[\mathrm{M}+\mathrm{K}]^{+}$} & $765 / 641$ \\
14 & $\mathrm{PC}(38: 4)$ & $\mathrm{C}_{46} \mathrm{H}_{84} \mathrm{NO}_{8} \mathrm{P}$ & 833 & {$[\mathrm{M}+\mathrm{Na}]^{+}$} & $773 / 649$ \\
15 & $\mathrm{PC}(38: 4)$ & $\mathrm{C}_{46} \mathrm{H}_{84} \mathrm{NO}_{8} \mathrm{P}$ & 849 & {$[\mathrm{M}+\mathrm{K}]^{+}$} & $789 / 665$ \\
\hline & & & & &
\end{tabular}


Table S3. Correlation coefficients among each individual tissue samples from 7 patients.

\begin{tabular}{|c|c|c|c|c|}
\hline & & Section 1 & Section 2 & Section 3 \\
\hline \multirow{3}{*}{ Patient 1} & Section 1 & 1.00 & 0.822 & 0.916 \\
\hline & Section 2 & 0.822 & 1.00 & 0.864 \\
\hline & Section 3 & 0.916 & 0.864 & 1.00 \\
\hline \multirow{4}{*}{ Patient 2} & & Section 1 & Section 2 & Section 3 \\
\hline & Section 1 & 1.00 & 0.892 & 0.911 \\
\hline & Section 2 & 0.892 & 1.00 & 0.928 \\
\hline & Section 3 & 0.911 & 0.928 & 1.00 \\
\hline \multirow{4}{*}{ Patient 3} & & Section 1 & Section 2 & Section 3 \\
\hline & Section 1 & 1.00 & 0.949 & 0.920 \\
\hline & Section 2 & 0.949 & 1.00 & 0.913 \\
\hline & Section 3 & 0.920 & 0.913 & 1.00 \\
\hline \multirow{4}{*}{ Patient 4} & & Section 1 & Section 2 & Section 3 \\
\hline & Section 1 & 1.00 & 0.805 & 0.953 \\
\hline & Section 2 & 0.805 & 1.00 & 0.868 \\
\hline & Section 3 & 0.953 & 0.868 & 1.00 \\
\hline \multirow{4}{*}{ Patient 5} & & Section 1 & Section 2 & Section 3 \\
\hline & Section 1 & 1.00 & 0.851 & 0.843 \\
\hline & Section 2 & 0.851 & 1.00 & 0.921 \\
\hline & Section 3 & 0.843 & 0.921 & 1.00 \\
\hline \multirow{4}{*}{ Patient 6} & & Section 1 & Section 2 & Section 3 \\
\hline & Section 1 & 1.00 & 0.931 & 0.952 \\
\hline & Section 2 & 0.931 & 1.00 & 0.933 \\
\hline & Section 3 & 0.952 & 0.933 & 1.00 \\
\hline \multirow{4}{*}{ Patient 7} & & Section 1 & Section 2 & Section 3 \\
\hline & Section 1 & 1.00 & 0.931 & 0.920 \\
\hline & Section 2 & 0.931 & 1.00 & 0.938 \\
\hline & Section 3 & 0.920 & 0.938 & 1.00 \\
\hline
\end{tabular}

(Note: Section1, section 2 and section 3 of patient 1, patient 2, patient 3, patient 4, patient 5, patient 6 , and patient 7 corresponded to the correlation analysis of (A-C), (D-F), (G-I), (J-L), (M-O), (P-R), and (S-U) in Figure 6.) 


\section{Reference}

(1) Xu, J.; Xu, S.; Xiao, Y.; Chingin, K.; Lu, H.; Yan, R.; Chen, H. Quantitative Determination of Bulk Molecular Concentrations of Beta-Agonists in Pork Tissue Samples by Direct Internal Extractive Electrospray Ionization-Mass Spectrometry, Anal. Chem. 2017, 89, 11252-11258. 